\title{
PENGARUH SAMPAH RUMAH TANGGA TERHADAP PELESTARIAN LINGKUNGAN DITINJAU DARI ASPEK BIOLOGI DI KOMPLEK PERUMAHAN GRAHA PERTIWI KEL. URUNG KOMPAS KEC. RANTAU SELATAN
}

\author{
EFFECT OF HOUSEHOLD WASTE VIEWED FROM THE ASPECT \\ ENVIRONMENTAL CONSERVATION BIOLOGY IN HOUSING \\ COMPLEX GRAHA PERTIWI KEL. UNDO KOMPAS \\ KEC. SOUTH RANTAU
}

\author{
Risma Delima Harahap
}

Sekolah Tinggi Ilmu Pendidikan Dan Keguruan, Universitas Labuhan Batu rismadelimaharahap@gmail.com

\begin{abstract}
Abstrak
Penelitian ini dilakukan untuk mengetahui pengaruh sampah rumah tangga terhadap pelestarian lingkungan ditinjau dari aspek biologi di komplek perumahan graha pertiwi kel. urung kompas kec. rantau selatan. Penelitian ini adalah penelitian lapangan (Field Research).Populasi penelitian adalah warga Komplek Graha Pertiwidalam menangani sampah warganya. Sampel dilakukan dengan menggunakan teknik stratifikasi random sampling.Untuk mengumpulkan data yang diperlukan dalam penelitian ini, maka dipergunakan alat pengumpulan data, yaitu observasi, wawancara, dan Library Research.Teknik pengumpul data yang peneliti gunakan adalah dengan melakukan wawancara dengan Pengusaha sebagai pengembang Komplek Graha Pertiwi.Data yang terkumpul dari lapangan penelitian akan disajikan secara sistematis. Hasil penelitian, bahwa sampah di Komplek Perumahan Graha Pertiwi berasal dari sampah rumah tangga dari penduduk yang bermukim di komplek tersebut. Adapun jenis sampah yang sering terlihat terdiri sampah organik dan sampah non organik. Setiap harinya di kompleks Graha Pertiwi para penghuni rata-rata bisa membuang sampah berkisar $1 \mathrm{~kg} /$ perharinya.Kesadaran masyarakat yang tinggi akan pengolahan sampah cukup besar dimana sampah mereka tumpuk di halaman depan rumah dan langsung dibakar, sehingga sampah tidak sempat menumpuk terlalu lama.Kendala yang dihadapi dan upaya penanggulangannyamasih rendahnya kesadaran masyarakat dalam menciptakan kebersihan lingkungan.Hal ini terlihat dari kebiasaan membuang sampah yang tidak pada tempatnya.Persepsi masyarakat tentang penanganan sampah masih tertumpu pada pemerintah, padahal masalah kebersihan adalah tanggung jawab bersama antara masyarakat dengan pemerintah,terbatasnya lahan untuk pengumpulan dan pembuangan sampah akhir, serta terbatasnya dana transportasi sampah. Sementara tumpukan sampah meningkat dari hari ke hari.
\end{abstract}

Kata Kunci: Sampah Rumah Tangga, Perumahan Graha Pertiwi

\begin{abstract}
This study was conducted to determine the effect of household waste to the environment in terms of aspects of biology at the housing complex kel housekeeping earth. nevertheless compass excl. southern shoreline. This research is a field (Field Research) is a research .Populasi residents handle garbage
\end{abstract}


Complex Graha Pertiwidalam citizens. Samples were done by using stratified random sampling.Untuk collect the necessary data in this study, the data collection tools used, ie observation, interviews, and Library Research.Teknik data collectors that researchers use is to conduct interviews with entrepreneurs as a developer Complex Graha Pertiwi the data collected from the field study will be presented systematically. The results of the research, that rubbish in Housing Complex Graha Pertiwi derived from household waste from residents who live in the complex. The type of waste that is often seen is composed of organic waste and garbage in the complex non organik. Setiap day Graha Pertiwi inmates on average to dispose of waste ranging from $1 \mathrm{~kg} /$ perharinya.Kesadaran high community waste management is big enough where their garbage stacked on the front page house and burned, so that the waste could not accumulate too lama.Kendala faced and penanggulangannyamasih efforts in creating public awareness of cleanliness lingkungan.Hal is seen from a habit of throwing garbage on tempatnya.Persepsi community about waste management is still concentrated in the government, whereas hygiene problem is a shared responsibility between the public and the government, the limited space for the collection and final disposal, as well as limited transportation funds rubbish. While a pile of garbage is increasing day by day.

Keywords: Household Waste, Graha Pertiwi

\section{PENDAHULUAN}

Sampah merupakan permasalahan yang dihadapai hampir setiap masyarakat terutama yang berada di perkotaan atau daerah yang padat penduduknya. Di daerah perkotaan terutama kota-kota politan seperti kota Rantauprapat, masalah sampah ini ditangani sebuah perusahaan daerah melalui dinas kebersihan, ini berarti bahwa masalah sampah sudah menyangkut hajat orang banyak, sampah tentunya identik dengan kebersihan dan berkaitan erat dengan kesehatan. Maka dari itu masalah sampah ini sangat urgen pengelolaannya.

Sampah berarti sesuatu yang tidak berguna atau tidak dapat dimanfaatkan lagi sehingga harus dimusnahkan jika tidak tentu akan menganggu, berbau busuk dan tidak baik. Namun tidak demikian halnya saat ini, pada zaman modern dan serba digital kini semua dapat diolah, demikian juga halnya dengan sampah.Banyak barang-barang yang sudah difonis tak berguna tetapi dapat didaur ulang dengan teknologi sehingga dapat menghasilkan produk baru yang memberikan manfaat bagi kehidupan manusia.Dengan demikian keberadaan sampah tidak lagi menjadi masalah dan mengganggu lingkungan hidup.Namun sebaliknya jika sampah dibiarkan, tidak diurus dapat menimbulkan permasalahan yang berkaitan dengan keindahan, kebersihan, kesehatan dan kerusakan lingkungan.

Hal ini jelas terlihat sebagaimana fenomena yang terjadi seperti membuang sampah sembarangan di sungai yang mengakibatkan banjir, penggundulan hutan yang mengakibatkan longsor dan berbagai bencana lain yang disebabkan oleh kecerobohan manusia serta tindakan 
semena-mena terhadap alam. Akan halnya sampah, setiap orang menghasilkan sampah, belum lagi sampah rumah tangga, industri atau pabrik-pabrik yang mengeluarkan limbah, hal ini memerlukan usaha dan kedisiplinan agar sampah yang terbuang tersebut tida snimbulkan masalah dan juga perlu pemikiran agar sampah yang terbuang dapat dimanfaatkan Kembali.

\section{KAJIAN PUSTAKA}

\section{a. Pengertian Sampah.}

Sampah (refuse) adalah "sebagian dari sesuatu yang tidak dipakai, tidak disenangi atau sesuatu yang harus dibuang, yang umumnya berasal dari kegiatan yang dilakukan oleh manusia (termasuk kegiatan industri), tetapi bukan biologis (karena human waste tidak termasuk didalamnya) dan umumnya bersifat padat". Sumber sampah bisa bermacam-macam, diantaranya adalah : dari rumah tangga, pasar, warung, kantor, bangunan umum, industri, dan jalan.

Faktor yang mempengaruhi jumlah sampah selain aktivitas penduduk antara lain adalah : “jumlah atau kepadatan penduduk, sistem pengelolaan sampah, keadaan geografi, musim dan waktu, kebiasaan penduduk, teknologi serta tingkat sosial ekonomi”.

Berdasarkan komposisi kimianya, maka sampah dibagi menjadi sampah organik dan sampah anorganik. Penelitian mengenai sampah padat di Indonesia menunjukkan "bahwa 80\% merupakan sampah organik, dan diperkirakan $78 \%$ dari sampah tersebut dapat digunakan kembali”.

Menurut Murtadho dan Said, "sampah organik dibedakan menjadi sampah organik yang mudah membusuk (misal: sisa makanan, sampah sayuran dan kulit buah) dan sampah organik yang tidak mudah membusuk (misal : plastik dan kertas)". Kegiatan atau aktivitas pembuangan sampah merupakan "kegiatan yang tanpa akhir.Oleh karena itu diperlukan sistem pengelolaan sampah yang baik.Sementara itu, penanganan sampah perkotaan mengalami kesulitan dalam hal pengumpulan sampah dan upaya mendapatkan tempat atau lahan yang benar-benar aman”.

\section{b. Kondisi Pengolahan Sampah Saat Ini.}

Jumlah penduduk Indonesia telah meningkat menjadi hampir dua kali lipat selama 25 tahun terakhir, yaitu dari 119,20 juta jiwa pada tahun 1971 bertambah menjadi 198,20 juta jiwa 
pada tahun 1996 dan bertambah kembali menjadi 204,78 juta jiwa pada tahun 1999. Jika tingkat pertumbuhan penduduk ini tidak mengalami perubahan positif yang drastis maka pada tahun 2020 jumlah penduduk Indonesia diperkirakan akan mencapai 262,4 juta jiwa dengan asurnsi tingkat pertumbuhan penduduk alami sekitar 0,9\% per tahun”.

Pertambahan penduduk ini diperkirakan tidak akan tersebar merata, tetapi akan terkonsentrasi di daerah perkotaan. Hal ini dikarenakan kawasan perkotaan merupakan tempat yang sangat menarik bagi masyarakat untuk mengembangkan kehidupan sosial ekonomi.Selain itu, pembangunan ekonomi Indonesia melalui jalur industrialisasi berpengaruh langsung terhadap pembangunan perkotaan.

Pada tahun 1980 persentase jumlah penduduk kota di Indonesia adalah 27,29\% dari jumlah penduduk Indonesia, sementara pada tahun 1990 persentase tersebut bertambah menjadi 30,93\%. Diperkirakan pada tahun 2020 persentase jurnlah penduduk kota di Indonesia mencapai $50 \%$ dari jumlah penduduk Indonesia".

Akibat dari semakin bertambahnya tingkat konsumsi masyarakat serta aktivitas lainnya adalah bertambahnya pula buangan/limbah yang dihasilkan.Limbah/buangan yang ditimbulkan dari aktivitas dan konsumsi masyarakat yang lebih dikenal sebagai limbah domestik telah menjadi permasalahan lingkungan yang harus ditangani oleh pemerintah dan masyarakat itu sendiri.

Limbah domestik tersebut, baik itu limbah cair maupun limbah padat menjadi permasalahan lingkungan karena secara kuantitas maupun tingkat bahayanya mengganggu kesehatan manusia, mencemari lingkungan, dan mengganggu kehidupan makhluk hidup lainnya. Khusus untuk sampah atau limbah padat rumah tangga, peningkatan jumlah sampah yang dihasilkan di Indonesia diperkirakan akan bertambah 5 kali lipat pada tahun 2020. Rata-rata produksi sampah tersebut diperkirakan meningkat dari 800 gram per hari per kapita pada tahun 1995 menjadi 910 gram per hari per kapita pada tahun 2000”.

Jika pengelolaan sampah tersebut tetap tidak ditangani dengan baik akan dapat menyebabkan timbulnya berbagai permasalahan seperti :

1. Gangguan kesehatan 
2. Penanganan sampah yang tidak baik dapat menyebabkan timbunan sampah yang dapat menjadi sumber kebakaran.

3. Dapat menutup saluran air sehingga meningkatkan masalah-masalah kesehatan yang berkaitan dengan banjir dan tanah-tanah yang tergenang air.

4. Sebanyak $20 \%$ sampah yang dihasilkan dibuang ke kali/sembarangan menyumbang sekitar $60 \%$ - 70\% pencemaran sungai.

Sampai dengan saat ini, pengelolaan persampahan yang dilakukan oleh pemerintah masih menggunakan pendekatan end of pipe solution.Pendekatan ini menitikberatkan pada pengelolaan sampah ketika sampah tersebut telah dihasilkan, yaitu berupa kegiatan pengumpulan, pengangkutan, dan pembuangan sampah ke Tempat Pembuangan Akhir (TPA) sampah.

Dinas Kebersihan dan Masyarakat melakukan pengurangan produksi sampah dengan dua tahapan, yaitu:

\section{1). Mengurangi sampah sejak dari sumbernya.}

Dalam kegiatan ini masyarakat melakukan kegiatan pemilahan di tempat masing-masing.

2). Mengurangi sampah yang masuk ke TPA.

Dalam kegiatan ini masyarakat sebagai penghasil sampah membuang sampah tanpa pethilahan terlebih dahulu. Selanjutnya sekelompok masyarakat yang lain memilah sampah yang sudah terkumpul di lokasi transfer (TPS) untuk diambil bagian yang masih bermanfaat, sebagian untuk kompos dan bagianlainnya dibuang ke TPA

Pewadahan SampahTidak ada ketentuan tentang pewadahan sampah yang harus digunakan oleh masyarakat, baik bentuk, ukuran maupun bahan wadah sampah. Pengadaan dan pemeliharaan wadah sampah merupakan tanggung jawab masing-masing penghasil sampah baik kelompok masyarakat dalam pemukiman ataupun di pusat kegiatan yang lain

Pengumpulan Sampah,Fasilitas pengumpulan yang digunakan oleh kota-kota yang disurvai dibedakan atas fasilitas yang diletakkan di suatu lokasi dan fasiltas yang bergerak. Fasilitas yang diletakkan di suatu lokasi bisa berbentuk Bak, Tong, Dipo atau Kontainer.Sedangkan fasilitas pengumpulan yang bergerak bisa berfungsi pula sebagai sarana 
pemindahan (transfer) dan juga sarana pengangkutan (transport). Bentuk sarana pengumpulan yang digunakan oleh dinas pengelola sampah di kota-kota di Indonesia adalah Becak sampah, Gerobak, mobil pick-up, dan truk. Tingkat pelayanan pengumpulan sampah sampai dengan TPA bervariasi dari $60,98 \%$ sampai dengan $89,22 \%$.

\section{c. Pengelolaan dan Pelestarian Lingkungan Hidup.}

Masalah utama lingkungan hidup di Indonesia adalah rendahnya kesadaran masyarakat, lemahnya penegakan hukum oleh aparatur negara, tidak adanya koordinasi antara sektor pemerintah, dan kurangnya partisipasi masyarakat, negara, dan dunia internasional.Pihak mancanegara seringkali mengecam kerusakan lingkungan di Indonesia, tetapi terus menikmati sambil mendukung diam-diam -- pencurian kayu ilegal, pencurian ikan dan penghancuran terumbu karang, serta eksploitasi pertambangan yang mencemari lingkungan sekitar dan merusak hutan lindung.

Prioritas masalah ditujukan bagi penyediaan air bersih untuk seluruh penduduk di segenap pelosok desa dan kota. Kebijakan privatisasi sumber air tak boleh mengorbankan kepentingan publik yang paling asasi.Selanjutnya, pemeliharaan hutan dan daerah resapan air sebagai sumber kehidupan. Kebersihan sungai, pantai dan laut juga mesti dijaga, antara lain dengan mekanisme pengelolaan limbah terintegrasi. Pada akhirnya, keaneragaman hayati (spesies) di daratan dan lautan merupakan aset nasional yang tak ternilai harganya.

\section{d. Mekanisme Pengolahan Sampah.}

Melihat permasalahan sampah yang demikian rumit, untuk mengelola persampahan hal pertama yang harus diperhatikan adalah kebijakan dari pemerintah yang dibuat dengan pendekatan menyeluruh sehingga dapat dijadikan payung bagi penyusunan kebijakan ditingkat pusat maupun daerah.Belum adanya kebijakan pemerintah tersebut menyulitkan pengelolaan persampahan. Kebijakan strategis yang telah ditetapkan oleh pemerintah baru pada tahap aspek teknis yaitu dengan melakukan pengurangan timbulan sampah dengan menerapkan Reduce, Reuse dan Recycle ( 3 R ), dengan harapan pada tahun 2025 tercapai "zero waste“.

Untuk menerapkan indikator tersebut diatas dapat dilakukan beberapa hal pada tahapan pengelolaan persampahan, yaitu: 
1. Pada tahap pengumpulan sampah disumber timbunan harus menerapkan program penghematan lahan TPA yaitu dengan melakukan pemisahan jenis-jenis sampah (sampah organik dan non organik).

2. Tempat pembuangan sementara sedapat mungkin dilakukan dengan menggunakan kontainer tertutup agar mudah diangkut sehingga penggunaan truk akan semakin efisien dan tidak menimbulkan kemacetan lalu lintas pada saat pemindahan sampah dari TPS ke truk pengangkut.

3. Dengan menggunakan kontainer sebagai TPS maka, truk pengangkut yang digunakan haruslah yang sesuai dengan kontainer tersebut.

Tempat pembuangan akhir (TPA) yang direkomendasikan oleh para ahli dengan menggunakan sistem sanitary landfill dapat dilengkapi dengan sarana pengomposan dan pemanfaatan sampah menjadi bahan baku daur ulang. Sisa sampah yang tidak dapat didaur ulang ataupun dibuat menjadi kompos kemudian dibakar dan disimpan dalam kolam sanitary landfill. Proses ini dapat dinamakan Instalasi pengolahan sampah terpadu (IPST).

Proses daur ulang, produksi kompos dan pembakaran tersebut bertujuan untuk memperkecil volume sampah yang dihasilkan, sehingga pembuangan sampah pada kolam sanitary landfill dapat diperkecil dan akhirnya dapat menghemat penggunaan lahan TPA.

Pembuatan kompos dapat dilakukan dengan beberapa macam teknologi, diantaranya menggunakan salah satu metodologi dibawah ini;

1. metodologi aerasi;

2. metodologi turning over bahan kompos (membolak balik bahan kompos)

3. metodologi open air atau reactor based.

Pemilihan jenis metodologi yang tepat perlu mempertimbangkan beberapa hal diantaranya adalah sebagai berikut;

1. Proses yang digunakan haruslah ramah ters lhadap lingkungan;

2. Biaya investasi tidak terlalu tinggi/ terjangkau;

3. Biaya operasional dan perawatan pembuatan kompos cukup murah;

4. Kualitas kompos yang dihasilkan cukup baik dibandingkan dengan pupuk kimia buatan; 
5. Harga kompos dapat terjangkau oleh masyarakat dan penggunaannya dapat bersaing dengan pupuk kimia buatan;

6. Menggunakan tenaga kerja yang bersifat padat karya.

Kompos adalah pupuk alami (organik) yang terbuat dari "bahan-bahan hijauan dan bahan organik lain yang sengaja ditambahkan untuk mempercepat proses pembusukan, misalnya kotoran ternak atau bila dipandang perlu, bisa ditambahkan pupuk buatan pabrik, seperti urea”.

\section{METODE}

Penelitian ini adalah penelitian lapangan (Field Research) yang penulis lakukan pada Komplek Perumahan Graha Pertiwi yang terletak di Jln. Tapian NauliKelurahan Urung Kompas, Kecamatan Rantau Selatan Kabupaten Labuhanbatu.Populasi penelitian adalah Komplek Graha Pertiwidalam menangani sampah warganya. Sampel dilakukan dengan menggunakan teknik stratifikasi random sampling (secara acak dan bertingkat).Untuk mengumpulkan data yang diperlukan dalam penelitian ini, maka dipergunakan alat pengumpulan data, yaitu observasi, wawancara, dan Library Research.Teknik pengumpul data yang peneliti gunakan adalah dengan melakukan wawancara dengan Pengusaha sebagai pengembang Komplek Graha Pertiwi, para warga yang penulis jadikan sampel.Data yang terkumpul dari lapangan penelitian akan disajikan secara sistematis.

\section{HASIL PENELITIAN}

\section{Keadaan Sampah di Komplek Perumahan Graha Pertiwi.}

Sampah di Komplek Perumahan Graha Pertiwi umumnya berasal dari sampah rumah tangga dari penduduk yang bermukim di komplek tersebut. Adapun jenis sampah yang sering terlihat terdiri sampah organik dan sampah non organik.Setiap harinya di kompleks Graha Pertiwi para penghuni rata-rata bisa membuang sampah berkisar $1 \mathrm{~kg} /$ perharinya. Bila diasumsikan jika satu rumah tangga mampu membuang sampah sebanyak $1 \mathrm{Kg}$ perharinya bila dikalikan dengan jumlah kepala keluarga yang tinggal di kompleks tersebut sebanyak 100 kepala keluarga, maka sudah $100 \mathrm{Kg}$ sampah berada dalam satu pemukiman dengan jumlah kepala keluarga hanya 100 kepala keluarga.

Kesadaran masyarakat yang tinggi akan pengolahan sampah cukup besar terutama warga kompleks Graha Pertiwi dimana sampah mereka tumpuk di halaman depan rumah dan langsung 
dibakar, sehingga sampah tidak sempat menumpuk terlalu lama. Dengan cara seperti ini upaya yang paling efektif untuk mengurangi polusi. Hal ini mereka lakukan karena becak pengangkutan sampah dari Dinas Kebersihan Labuhanbatuseminggu hanya 2 kali masuk di daerah ini, jadi upaya mengurangi tingkat penumpukan sampah dilakukan dengan cara dibakar dan ditanam.

\section{Upaya Pelastarian Lingkungan di Komplek Perumahan Graha Pertiwi.}

Perumahan Graha Pertiwi, para pengembang melirik lahan jauh dari Rantauprapat, yaitu di Jalan Tapian Nauli itu sendiri dimana geografis daerahnya berbentuk iklim perbukitan, sehingga bila dijadikan perumahan akan memberi daya tarik sebagai perumahan yang indah. Hasil penelitian penulis di Komplek perumahan ini ada beberapa hal yang menarik menjadikan perumahan ini banyak diminati para pembeli.Perumahan Graha Pertiwi dengan nuansa lokasi lahannya yang sedikit berbukit-bukit, akan memberi daya tarik tersendiri bagi pembeli yang ingin tinggal di perumahan ini.

Selain itu nilai ekonomis yang didapat bahwa harga dari rumah yang dibangun dapat dijangkau oleh masyarakat menengah ke bawah, karena pembeliannya dapat secara tunai maupun diangsur.

Proses Pelastarian lingkungan tidak terlepas dari peran serta masyarakat, terutama warga yang bertempat tinggal di Kompleks Graha Pertiwi. Namun karena kesibukan dan aktivitas kerja yang padat, karena pada umumnya warga yang tinggal di perumahan ini adalah para pekerja baik di pemerintahan maupun di perusahan swasta yang di Labuhanbatu, jadi waktu yang diluangkan juga cukup sedikit untuk dapat ikut serta dalam pelestarian lingkugan di Kompleks tersebut. Jadi salah satu cara yang diterapkan oleh pengembang adalah dengan memperkerjakan sebagian masyarakat sebagai tenaga kebersihan di kompleks ini. Tentunya dengan berdirinya perumahan ini membuka kesempatan kerja kepada masyarakat di sekitar kompleks.Dalam hal pengolahan sampah, warga di kompleks turut berperan aktif dalam menjaga kebersihan. Setiap sampah rumah tangga baik organik maupun non organik dikumpulkan di depan rumah dan selanjutnya akan diambil oleh petugas kebersihan yang telah ditunjuk. Dalam hal ini akan memberi pemasukan bagi para petugas kebersihan. 
Namun yang disayangkan belum adanya tenaga terampil yang mampu mengolah sampah rumah tangga yang di dapat dari kompleks tersebut, sehingga setiap sampah yang mereka kumpulkan hanya sebatas memilih barang-barang non organik untuk dapat dijual kembali ke penampungan seperti plastik, botol maupun kertas.Sedangkan sampah organik belum ada yang mampu mengolah bahan tersebut menjadi pupuk kompos.Karena kebanyakan sampah tersebut hanya dibuang oleh pemilih rumah dan diambil oleh petugas kebersihan kompleks kemudian dikumpulkan di tempat penampungan lalu dibakar.

Belum mampunya petugas kebersihan kompleks menjadikan sampah organik untuk diolah menjadi kompos membuat sampah-sampah tersebut hanya terbuang percuma.Dalam hal ini tentunya pihak pengembang harus berperan aktif mencari solusi bagaimana memberikan diklat dan latihan kepada petugas kebersihan sehingga kedepannya sampah-sampah berbahan organik dapat diolah menjadi suatu pemasukan.

\section{Pengaruh Sampah Rumah Tangga Terhadap Pelestarian Lingkungan.}

Sampah sebenarnya hasil buangan dari para manusia, tetapi keberadaan sampah bisa berdaya guna bagi kelangsungan kehidupan di muka bumi ini. Sepanjang sampah tidak dikelola dengan baik tentu ia akan menjadi malapetaka bagi manusia dan alam ini.Sebenarnya sampah bisa menjadi berdaya guna bila ditangani dengan benar dan adanya kesadaran dari para manusia itu sendiri bagaimana mengatasi sampah itu sendiri.Dari mulai perjalanan sampah ke Tempat Pembuangan Akhir (TPA) dan sampai penumpukan sampah, jelas akan memberi dampak negatif buat manusia itu sendiri. Disinilah peran manusia itu dituntut untuk andil dalam mengatasi sampah, sehingga sampah bukan problem yang tidak dapat diatasi.

Sampah dapat dikelola dan dikembangkan dengan berbagai ragam kebutuhan asalkan kita mau mengelolanya dan memberi kesadaran dari manusia itu sendiri. Untuk menjadikan sampah menjadi nilai baik untuk manusia, bukan menjadikan sampah sebagai perusak lingkungan dapat dimulai dari pemisahan mana sampah yang sifatnya organik dan sampah non organik.Sampah non organik, bila kita mau memilahnya dan membedakannya dengan tidak membuang sembarangan, maka sampah-sampah tersebut dapat menjadi penghasilan dan dapat didayagunakan dengan cara menjual langsung kepada penampungan khusus produk daur ulang atau menjadikannya sebagai bentuk kerajinan seperti bahan berdasarkan pembungkus mie, roti dan lainnya. 


\section{Kendala Yang Dihadapi Dan Upaya Penanggulangannya}

Dalam pembahasan dari penelitian ini tentunya ada beberapa kendala yang penulis temukan diantaranya :

1. Masih rendahnya kesadaran masyarakat dalam menciptakan kebersihan lingkungan. Hal ini terlihat dari kebiasaan membuang sampah yang tidak pada tempatnya.

2. Persepsi masyarakat tentang penanganan sampah masih tertumpu pada pemerintah, padahal masalah kebersihan adalah tanggung jawab bersama antara masyarakat dengan pemerintah

3. Terbatasnya lahan untuk pengumpulan dan pembuangan sampah akhir, serta terbatasnya dana transportasi sampah. Sementara tumpukan sampah meningkat dari hari ke hari.

\section{ANALISA DATA}

Sebagai analisa dari pembahasan ini tentunya sampah dapat dijadikan bahan alternatif untuk mendayagunakan sampah, sehingga sampah tidak menjadi bahan yang harus dibuang secara percuma.Agar sampah tidak menjadi penumpukan di tempat pembuangan sampah, perlu adanya peran serta masyarakat untuk mengelola sampah dengan baik. Untuk dapat menjadikan sampah tepat guna ada beberapa cara yang dapat dilakukan, yaitu bermula dari keluarga sendiri. Peran kelurga dalam rumah tangga agar dapat memisahkan sampah organik dan sampah non organik, kemudian membuangnya ditempat yang telah disediakan, dimana sampah organik dijadikan satu kantongan dan sampah non organik satu kantongan.Kemudian sampah-sampah tersebut dapat dikelola selama sumber daya manusia itu ada.Sampah yang sifatnya organik dari sisa sayuran, daun-daunan, ikan dan sisa makanan dapat dikelola menjadi kompos.Sedangkan sampah non organik dapat dijual dipenampungan.

\section{PEMBAHASAN}

Selama ini tahapan penanganan sampah yang ada dimulai dari pengumpulan sampah pada tingkat rumah tangga, kemudian diangkut ke tempat pembuangan sampah tingkat RW dan kelurahan atau yang umum dikenal dengan nama Tempat Pembuangan sampah Sementara (TPS), hingga akhirnya diangkut oleh Dinas Kebersihan kota ke Tempat Pembuangan sampah Akhir (TPA). 
Bila dilihat dari mata rantai pembuangan sampah tersebut, nampaklah beban TPA amat berat mengingat harus menampung sampah yang ada dari seluruh bagian kota. Hal inilah yang dirasakan menjadi masalah oleh kebanyakan kota besar seperti halnya kota Rantauprapat. Khusus untuk penanganan sampah di perkotaan, berdasarkan informasi dari PD Kebersihan diketahui bahwa dari tahun ke tahun biaya yang dibutuhkan untuk penyediaan sarana transportasi (gerobak sampah,truk sampah dan loader / buldozer) dan lahan tempat pembuangan sampah (baik TPS dan TPA) makin meningkat sementara alokasinya masih terbatas. Oleh karena itu, PD Kebersihan saat ini menetapkan 4 strategi, yaitu : Meminimalkan sampah; mendaur ulang dan pembuatan kompos; meningkatkan pelayanan pengangkutan sampah serta penanganan sampah di tempat pembuangan akhir sampah dengan cara yang akrab/ramah lingkungan.

Berpijak dari kondisi yang ada, untuk memecahkan masalah sampah harus melihat pola penanganan yang ada saat ini.Dengan demikian pada titik mana dari mata rantai pembuangan sampah tersebut dapat dilakukan perbaikan dan penyempurnaan sehingga sampah yang masuk ke TPA pada akhirnya hanya berupa sampah yang benar-benar tidak dapat diolah kembali.

\section{KESIMPULAN}

1. Keadaan sampah di komplek Perumahan Graha Pertiwiumumnya terdiri dari sampah rumah tangga dan ditambah hasil sapuan daun-daunan dari pepohonan untuk penghijauan kompleks.

2. Upaya pengolahan sampah di kompleks Graha Pertiwibelum dapat terealisasi dengan baik. Karena kebanyakan sampah yang dibuang belum dapat dimanfaatkan, baik warga pemukiman maupun petugas kebersihan yang ditugaskan oleh perusahan sebagai pemilik kompleks.

3. Pelestarian lingkungan di areal kompleks sudah cukup maksimal, dimulai dari penanganan sampah dengan memperkerjakan masyarakat sekitar kompleks untuk menjadi petugas kebersihan yang setiap harinya mereka bertugas mengumpulkan sampah dari dalam komplek dan dikumpulkan di Tempat Pembuangan Sementara kemudian di bakar. Sedangkan untuk penghijauan sudah cukup maksimal dengan banyak penghijauan yang dilakukan di areal kompleks dan di luar kompleks.

4. Sampah bisa jadi sumber untuk pelestarian lingkungan bila dapat dikelola dengan baik. Tentunya disini dibutuhkan tenaga terampil untuk mengolah sampah tersebut. Karena rata- 
rata sampah yang dibuang warga kompleks kebanyakan sampah organik dari sisa makanan dan masakan warga.

\section{DAFTAR PUSTAKA}

Ahmadi Abu, Ilmu Pendidikan, (Semarang, CV. Toha Putra, 1977)

Ali, Mohammad, Penelitian Kependidikan Prosedur \& Strategi, (Bandung, Angkasa, 1982).

Arikunto, Suharsimi, Prosedur Penelitian Suatu Pendekatan Praktek, (Jakarta, Rineka Cipta, 1983).

Azwar, Asrul, Pengantar Ilmu Kesehatan Lingkungan, (Jakarta, Mutiara Sumber Widya, 1990).

Chart, Wall, Sampah dan Pengolahannya, (Jakarta, Direktorat Jenderal Pendidikan Dasar Menengah, Depdikbud, $\mathrm{tt}$ ).

Brata, Sumadi Surya, Psikologi Pendidikan, (Jakarta, PT. Raja Grafindo Persada, 1998)

Depkes, RI, Pedoman Bidang Studi Pembuangan Sampah, Akademi Penilik Kesehatan Teknologi Sanitasi (APKTS), (Jakarta, Proyek Pengembangan Pendidikan Tenaga Sanitasi Pusat Departemen Kesehatan, 1987).

Murtadho, Djuli dan Said Gumbira, Penanganan dan Pemanfaatan Limbah Padat,(Jakarta, Mediyatama Sarana Perkasa, 1987).

Outerbridge, Thomas (ed), Limbah Padat di Indonesia : Masalah atau Sumber Daya. (Jakarta, Yayasan Obor Indonesia, 1991).

Pusat Informasi Lingkungan Hidup, State of The Environment Report Indonesia 2001, Bapedal 2001.

Sudjana, M.A, Metode Statistika, (Bandung, Tarsito, 1992).

Suryani, M. Ahmad R., dan Mudi R, Lingkungan Sumber Daya Alam dan Kependudukan Dalam Pembangunan, (Jakarta, Universitas Indonesia Press, 1997).

Unus, Suriawiria, Pupuk Organik Kompos dari Sampah, Bioteknologi Agroindustri. (Bandung, Humaniora Utama Press, 2004).

Usaid, Pengelolaan Sampah Berbasis Masyarakat, (Jakarta, Environmental Serivices Program, $\mathrm{tt})$.

Wied, Hary Apriaji, Memproses Sampah. (Jakarta, Penebar Swadaya, 2004). 